\title{
Lack of Reproduction in Muskoxen and Arctic Hares Caused by Early Winter?
}

\author{
L. DAVID MECH ${ }^{1}$
}

\author{
(Received 6 January 1999; accepted in revised form 12 July 1999)
}

\begin{abstract}
A lack of young muskoxen (Ovibos moschatus) and arctic hares (Lepus arcticus) in the Eureka area of Ellesmere Island, Northwest Territories (now Nunavut), Canada, was observed during summer 1998, in contrast to most other years since 1986. Evidence of malnourished muskoxen was also found. Early winter weather and a consequent $50 \%$ reduction of the 1997 summer replenishment period appeared to be the most likely cause, giving rise to a new hypothesis about conditions that might cause adverse demographic effects in arctic herbivores.
\end{abstract}

Key words: arctic hare, Lepus arcticus, Ellesmere Island, malnutrition, muskox, Ovibos moschatus, population, reproduction, snow, weather, winter severity

RÉSUMÉ. Durant l'été 1998, et ce, à la différence de la plupart des années depuis 1986, on a relevé un manque de jeunes boeufs musqués (Ovibos moschatus) et de lièvres arctiques (Lepus arcticus) dans la région d'Eureka de l'île d'Ellesmere (Territoires du Nord-Ouest [maintenant Nunavut], au Canada). On a aussi découvert des preuves de malnutrition chez le boeuf musqué. La cause la plus probable semble être un hiver hâtif et la baisse résultante de 50 p. cent de la période de restauration estivale en 1997, ce qui donne lieu à une nouvelle hypothèse sur les conditions qui pourraient avoir des répercussions démographiques nuisibles chez les herbivores de l'Arctique.

Mots clés: lièvre arctique, Lepus arcticus, île d'Ellesmere, malnutrition, boeuf musqué, Ovibos moschatus, population, reproduction, neige, temps, rigueur de l'hiver

Traduit pour la revue Arctic par Nésida Loyer.

\section{INTRODUCTION}

Because of the remoteness and inaccessibility of Canada's High Arctic islands, few details are known about their wildlife populations and the factors that affect these populations. For example, there appear to be only three publications touching on arctic hare ecology (Parker, 1977; Klein and Bay, 1995; Schaefer et al., 1996) and, although muskoxen have been well studied, "we have no idea why periodic declines occur" (Theberge, 1972:28). Thomas et al. (1981) saw extreme winter weather as a logical cause of muskox declines, and Gunn et al. (1989) proposed a hypothesis involving above-average snow depths in spring. Excessive snowfall and ice crust have also been blamed for muskox declines, yet the effects of these conditions vary throughout muskox range (summarized by Forchhammer and Boertmann, 1993).

Densities of arctic mammals tend to be lower than those of mammals inhabiting lower latitudes, so population and productivity declines are more serious and thus more noteworthy. This article reports evidence of such a decline in muskox and arctic hare populations on part of Ellesmere Island during winter 1997-98, when neither ice crusts nor excessively deep snow prevailed. An alternative weatherbased hypothesis is offered.

\section{STUDY AREA AND METHODS}

The study area included a $150 \mathrm{~km}^{2}$ region of the Fosheim Peninsula in a $180^{\circ}$ arc north of Eureka, Ellesmere Island, Nunavut, Canada (all within about $9 \mathrm{~km}$ of $80^{\circ} \mathrm{N}, 86^{\circ} \mathrm{W}$ ). The area, extending from Eureka Sound to Remus Creek and from Slidre Fiord to Eastwind Lake, included shoreline, hills, lowlands, creek bottoms, and the west side of Blacktop Ridge. An associate, Layne Adams, and I spent 1-11 July 1998 in this area on all-terrain vehicles, following a pair of wolves Canis lupus (Mech, 1994). Adams and I also surveyed the surrounding area with binoculars for prey animals, in much the same manner that my assistants and I have practiced for one to six weeks each summer in the same area since 1986 (Mech, 1995, 1997). Because both muskoxen and arctic hares were common residents of the area during most years and were not the focus of our studies, no standardized counts were made. However, general field notes were sufficient to document that during most summers both species and their young were present.

Data on temperatures, precipitation, and snow cover for the study area, recorded at a weather station near sea level at Eureka, were obtained from Environment Canada (1998). Because most of the study area is considerably higher than the weather station, its temperature and snow conditions were more severe than records from the weather station

${ }^{1}$ U.S. Geological Survey, Northern Prairie Wildlife Research Center, 8711 - 37th St. SE, Jamestown, North Dakota 58401-7317, U.S.A.; mailing address: North Central Research Station, 1992 Folwell Ave., St. Paul, Minnesota 55108, U.S.A.; mechx002@tc.umn.edu

(C) The Arctic Institute of North America 
TABLE 1. Records of muskoxen and arctic hares observed during summers (1986-98) in the Eureka area of the Fosheim Peninsula, Ellesmere Island, Nunavut, Canada.

\begin{tabular}{|c|c|c|c|c|}
\hline Year & Dates & $\begin{array}{c}\text { Muskox } \\
\text { Calves }^{1}\end{array}$ & $\begin{array}{c}\text { Arctic Hare } \\
\text { Leverets }^{1}\end{array}$ & Remarks $^{2}$ \\
\hline 1986 & 4 July - 1 August & $\mathrm{x}$ & $\mathrm{x}$ & 131 muskoxen seen from $\mathrm{W}$ side of Blacktop Mt. in one day \\
\hline 1987 & 23 June - 10 August & $\mathrm{x}$ & $\mathrm{x}$ & \\
\hline 1988 & 20 June - 4 August & $\mathrm{x}$ & $\mathrm{x}$ & "16 young hares in one group" \\
\hline 1989 & 14 June - 10 August & $\mathrm{x}$ & $\mathrm{x}$ & 151 muskoxen and 200+ hares seen from W. side of Blacktop Mt. in one day \\
\hline 1990 & 21 June -9 August & $\mathrm{x}$ & 0 & "very few muskoxen this year;" "no young hares seen" \\
\hline 1991 & 13 June -8 August & ? & $\mathrm{x}$ & \\
\hline 1992 & 2 July - 6 August & $\mathrm{x}$ & $\mathrm{x}$ & 9 leverets seen in one group; muskox herds of up to 17 seen \\
\hline 1993 & 1 July -6 August & $\mathrm{x}$ & $\mathrm{x}$ & herd of 29 hares; many leverets everywhere \\
\hline 1994 & 30 June - 26 July & $\mathrm{x}$ & $\mathrm{x}$ & "many leverets seen" \\
\hline 1995 & 29 June - 7 July & ? & $?$ & \\
\hline 1996 & 25 June - 1 August & $\mathrm{x}$ & $\mathrm{x}$ & “"cloud' of 16 leverets;” "muskoxen seen daily everywhere” \\
\hline 1997 & $2-6$ July & $\mathrm{x}$ & $\mathrm{x}$ & "many adult hares and leverets;" "several small herds of muskoxen, some with calves" \\
\hline 1998 & $1-12$ July & 0 & 0 & herds of $3,3,7,7$, and 10 muskoxen seen \\
\hline
\end{tabular}

${ }^{1} \mathrm{x}=$ present; $0=$ absent (none seen despite extensive travel over long period); $?=$ travel too localized or too short to be certain.

${ }^{2}$ Quoted material is verbatim from field notes.

indicate. For example, fresh snow often covered upland parts of the study area but not the shore area where the weather station was located.

\section{RESULTS}

During most years, muskoxen and arctic hares and their young were seen regularly each summer (Table 1). During summer 1998, however, I observed only 30 muskoxen, in herds of 3, 3, 7, 7, and 10. Most of these herds were seen in the Eastwind Lake area from the west side of Blacktop Mountain, where in previous years up to 151 muskoxen had been counted. In 1998, the herds contained no calves.

Similarly, fewer arctic hares were seen in 1998 than in any previous summer, and not one leveret (young hare) was observed, even when my colleague and I were following a pair of wolves hunting leverets. In 1996, in contrast, I had watched a single wolf kill six leverets in one night. During every other summer except 1990 , leverets were common (Table 1). I also interviewed personnel from a weather station and a military base at Eureka and a scientist who had been on foot in the area for several weeks in 1997 and 1998. Although all had seen leverets in 1997, none had observed any in 1998.

The third difference between my 1998 prey observations and those of previous years was that in 1998 we found the remains of nine muskoxen that had died over winter. All had hollow long bones with no indication of fat, and only a few had been fed on by wolves. Two such remains were the most I had found in any previous summer. In addition, in July 1998 we watched two wolves kill an old cow muskox and found that the marrow fat in its femur was mostly depleted (Mech and Adams, 1999). During the summers of 1986, 1987, 1989, 1992, and 1994, I had found fresh wolf-killed muskoxen, but their femur marrow had been fully fat.
Unusually severe weather conditions might cause nutritional stress (Thomas et al., 1981; Gunn et al., 1989). But conditions for most of the previous fall, winter, and spring had fallen within long-term norms: that is, daily mean temperatures, monthly precipitation, monthly snowfall, and month-end snow cover for October 1997 through April 1998 were all within the norms for the study area or, for a few months, more favorable. No abnormally deep snow or snow crusts were recorded (Environment Canada, 1998).

However, winter weather began especially early. August and September 1997 were wetter and colder than long-term norms (Table 2). They were also wetter and colder than in 1996, after which reproduction in both muskoxen and hares was recorded in summer 1997 (Tables 1 and 2). Usually temperatures do not remain below freezing until about 5 September, and there is not more than $6 \mathrm{~cm}$ of snow cover until October; however, in 1997, temperatures remained below freezing or only slightly above after 17 August, and there was as much as $9 \mathrm{~cm}$ of snow cover by 27 August (Environment Canada, 1998). (Although $9 \mathrm{~cm}$ of snow is not deep, the wind distributes the snow in drifts that are much deeper in lowlands, where much of the vegetation grows.)

\section{DISCUSSION}

Together, these data strongly indicated that some pervasive factor had negatively affected both muskoxen and arctic hare populations during winter 1997-98. The fact that numbers, condition, and reproduction were affected in both species implies that the factor was related to nutrition: probably it was adverse weather conditions.

The only weather data that appeared extreme were those indicating that winter began considerably earlier than usual. Temperatures, precipitation, and snow cover in late August and September brought winter conditions five to six weeks earlier than the norm. Because daily minimum 
TABLE 2. Weather parameters in study area during months preceding winter $1997-98^{1}$ compared to long-term norms and to the same months preceding winter 1996-97 (Environment Canada, 1998).

\begin{tabular}{|c|c|c|c|c|c|c|c|c|c|c|c|c|}
\hline Month & \multicolumn{3}{|c|}{ Daily Mean Temperature (C) } & \multicolumn{3}{|c|}{ Monthly Precipitation (mm) } & \multicolumn{3}{|c|}{ Monthly Snowfall (cm) } & \multicolumn{3}{|c|}{ Month-end Snow Cover $(\mathrm{cm})$} \\
\hline September & -10.4 & -8.3 & -9.0 & 15.6 & 9.7 & 15.0 & 23.4 & 10.9 & 19.2 & 13.0 & 6.0 & 8.0 \\
\hline
\end{tabular}

${ }^{1}$ During October 1997 through April 1998, these parameters were normal or more favorable.

${ }^{2}$ 1961-90.

${ }^{3} 1947-90$.

temperatures do not usually rise above freezing until midJune (Environment Canada, 1998), most vegetation does not begin growing until late June. Thus, the usual summer replenishment period for herbivores is approximately from 1 July to 1 October, or three months.

However, the early onset of winter conditions in 1997 would have ended the replenishment period in midAugust, reducing it by about $50 \%$. This shortened feeding period appears to be the best explanation for the demographic problems observed in muskoxen and arctic hares during summer 1998.

Conceivably the relative dearth of these animals in 1998 might be attributable to some unusual distribution pattern. However, there is little reason to believe that both species would show such a pattern, for there is no evidence that the two are regularly associated (Schaefer et al., 1996). Furthermore, the lack of young of both species, when at least some adults were seen, evinces a population phenomenon that is real and bolsters the conclusion that the low numbers of adults seen reflected a reduction in population.

Because there was no evidence of either ice crusts or abnormally deep snow in spring, the population phenomenon I observed fit none of the usual hypotheses about muskox population declines (Thomas et al., 1981; Gunn et al., 1989, Forchhammer and Boertmann, 1993). Therefore I present a new hypothesis: that early onset of winter might cause adverse demographic effects in arctic herbivores by shortening their summer replenishment period.

\section{ACKNOWLEDGEMENTS}

This work was supported by the National Geographic Society, the U.S. Fish and Wildlife Service, the Biological Resources Division of the U.S. Geological Survey, and the U.S. Department of Agriculture, North Central Forest Experiment Station. The logistical support of the Polar Continental Shelf Project (PCSP) and Atmospheric Environment Services of Environment Canada is also gratefully acknowledged. I wish to thank Ann Gunn, Dennis Murray, and an anonymous reviewer for their helpful suggestions for improving this article. This is PCSP paper 00499.

\section{REFERENCES}

ENVIRONMENT CANADA. 1998. Weather records. http:// www.cmc.gc.ca/climate/

FORCHHAMMER, M., and BOERTMANN, D. 1993. The muskoxen Ovibos moschatus in north and northeast Greenland: Population trends and the influence of abiotic parameters on population dynamics. Ecography 16:299-308.

GUNN, A., MILLER, F.L., and McLEAN, B. 1989. Evidence for and possible causes of increased mortality of bull muskoxen during severe winters. Canadian Journal of Zoology 67: $1106-1111$.

KLEIN, D.R., and BAY, C. 1995. Digestibility of forage types by arctic hares. EcoScience 2:100-102.

MECH, L.D. 1994. Travel speeds of arctic wolves. Journal of Mammalogy 75:741-742.

-1995. A ten-year history of the demography and productivity of an arctic wolf pack. Arctic 48:329-332.

- 1997. The arctic wolf: Ten years with the pack. Stillwater, Minnesota: Voyageur Press.

MECH, L.D., and ADAMS, L.G. 1999. Killing of a muskox, Ovibos moschatus, by two wolves, Canis lupus, and subsequent caching. Canadian Field-Naturalist 113:673-675.

PARKER, G.R. 1977. Morphology, reproduction, diet, and behavior of the arctic hare (Lepus arcticus monstrabilis) on Axel Heiberg Island, Northwest Territories. Canadian Field-Naturalist 91: $8-18$.

SCHAEFER, J.A., STEVENS, S.D., and MESSIER, F. 1996. Comparative winter habitat use and associations among herbivores in the High Arctic. Arctic 49:387-391.

THEBERGE, J.B. 1972. Northern wildlife resources-will we lose by default? Nature Canada 1(3):26-32.

THOMAS, D.C., MILLER, F.L., RUSSELL, R.H., and PARKER, G.R. 1981. The Bailey Point region and other muskox refugia in the Canadian Arctic: A short review. Arctic 34:34-36. 